Millatī, Journal of Islamic Studies and Humanities Vol. 4, No. 1, Juni 2019: p. 53-68. DOI: 10.18326/mlt.v4i1. 53-68

p-ISSN : 2541-3627; e-ISSN 2540-9964

Website: http://millati.iainsalatiga.ac.id/index.php/millati/index

\title{
Maintaining Behavior for Preventing Disaster (Ecology Themed Tafsir of Perished Nation)
}

\author{
Ayusta Gilang Wanodya \\ Faculty of Ushuluddin, Adab and Humaniora, LAIN Salatiga, Indonesia \\ ayusta.wanodya@gmail.com
}

\begin{abstract}
Nowadays, Ecology themed interpretation becomes a popular mode of Qur'anic interpretation. This interpretation has ultimate goal to help human taking care of nature. As a reward, it is expected that nature would not cause disasters that inflict damages to human. In Qur'an, there are a lot of verses encouraging human for doing good in the earth. The approach that we used up till now for natural disasters prevention is approach relating to human efforts that directly affecting nature, such as not litter, illegal logging, etc. From the stories of perished nations in the Qur'an by terrifying disasters, this research tried to take lessons for the sake of conserving nature where we live. This research maps out that there is an indirect causality between human and nature as nature have also unknown section (ghaib) instead of material section that commonly known. This unknown section is a part of nature that obeying doing sujud and reciting tasybih to Allah. This section is related to how we behave to Allah and other human beings. If we behave properly, the nature will be good to us, and vice versa.
\end{abstract}

Keywords : Ecology themed interpretation, perished nations, causality, ghaib.

\begin{abstract}
Abstrak
Tafsir ekologi dewasa ini menjadi model tafsir al-Qur'an yang populer. Tafsir ini memiliki tujuan utama untuk membantu manusia menjaga lingkungan alam. Sebagai timbal baliknya agar alam tidak menimbulkan bencana yang dapat merugikan manusia. Dalam al-Qur'an terdapat banyak ayat yang menyeru manusia untuk tidak berbuat kerusakan di bumi. Pendekatan yang selama ini digunakan dalam pencegahan bencana alam adalah pendekatan terhadap usaha manusia yang secara langsung mempengaruhi alam, seperti tidak membuang sampah sembarangan, illegal logging, dsb. Dari kisah kaum-kaum yang dihancurkan dalam al-Qur'an dengan bencana yang mengerikan, penelitian ini ingin mengambil hikmah sebagai usaha menjaga lingkungan alam tempat kita hidup. Penelitian ini menemukan bahwa ada hubungan timbal balik tidak langsung (indirectly) antara manusia dan alam. Hal tersebut dikarenakan alam memiliki sisi ghaib, tidak hanya sisi materi saja yang lazim kita ketahui. Sisi ghaib ini adalah sisi alam yang tunduk, bersujud, dan bertasbih kepada Allah. Sisi ini berhubungan erat dengan bagaimana kita berperilaku terhadap Allah dan sesama manusia lainnya. Jika perilaku kita baik, maka alam pun akan baik kepada kita, begitu pula sebaliknya.
\end{abstract}

Kata Kunci: Tafsir ekologi, kaum yang dihancurkan, timbal balik, ghaib. 


\section{INTRODUCTION}

There is a reciprocal relationship between human and his environment, one which human affect his environment and vice versa. Human lives within his environment and can not be apart from it. There is a dynamic relationship between human and his environment. Changes in the environment will cause changes in human behavior to adapt to the new condition. These behavioral changes will, in turn, cause changes in the environment. As the dynamic-circular relationship between humans and their environment, in a good environment, humans grow and vice versa. ${ }^{1}$

It is evident that environment is very important for human. However, in recent decades, environmental problems has always plagued Indonesia. There is many disasters which caused material loss and even human fatalities. Every time disasters happen and befall human in a area, a rumor usually spreads saying that the disaster was caused by human behavior. Here, the behavior is not about how humans treat nature, but relating to moral sense to God and other creatures. This rumor is still commonly believed by people. However, some people do not trust it along with science explanation rapidly developed explaining disaster more rationally. Therefore, this study tries to trace whether rumors or myths are truly misguided in order to prevent nature from damage.

\section{Ecology-Themed Interpretation}

According to J.J.G Jansen research, contemporary modern Tafsir are mapped in three categories, namely 'ilmi, linguistics-fiological and practical Tafsir. ${ }^{2}$ Practical Tafsir is Tafsir related to the everyday problems of Ummah including environmental problems. Massive exploitation of natural resources and irregular management of environments make all harmonious elements turn into chaotic even end up in disaster. ${ }^{3}$ A number of disasters have hit Indonesia such as tsunamis, landslides, earthquakes, volcanic eruptions, tornadoes, smog and flash floods. Tafsir address this issue is included in ecology-themed Tafsir.

Tafsir, according to Ali al-Sabuni, is a science that can understand the book of Allah (al-Qur'an) which was revealed to the Prophet Muhammad, explain the meanings of Qur'an and explore the laws in it. ${ }^{4}$ The definition of ecology comes from word oikos which means resident, and logos which mean knowledge. ${ }^{5}$ Terminologically, the notion of ecology is defined variously by experts and observers. Otto Soemarwoto defines ecology with a simple language, namely the knowledge of the mutual relations of living things with their living environment. ${ }^{6}$ Similar things is also recorded by the Indonesian Dictionary (Kamus Besar Bahasa Indonesia). KBBI defines ecology as the science of reciprocal relations between living things and (conditions) surrounding environment.

\footnotetext{
${ }^{1}$ Tresna Sastrawijaya, Pencemaran Lingkungan, (Jakarta: Rineka Cipta, 2000), p. 7.

2 Abdul Mustaqim, Dinamika Sejarah Tafsir al-Qur'an, (Yogyakarta: Adab Press, 2014), p. 148.

${ }^{3}$ Fachruddin M. Mangunjaya, Konservasi Alam dalam Islam, (Jakarta: Yayasan Obor Indonesia), 2005, p. 9.

${ }^{4}$ Muhammad Ali Al-Sabuni, Al-Tibyan Fi 'Ulum Al-Qur'an, (Jakarta: Dar AlIslamiyah, 2003), p. 65.

${ }^{5}$ Soedjiran Resosoedarmo, dkk, Pengantar Ekologi, (Bandung: Remadja Karya Cv, 1984), p. 1.

${ }^{6}$ Ahmad Suhendra, Menelisik Ekologis dalam al-Qur'an, Jurnal Esensia, Vol XIV No. 1 April 2013.
} 
Therefore, ecology-themed tafsir is tafsir with ecological features produced by mufassir reflecting their alignments with ecological issues and desiring to give contribution and solutions to the ecological problems afflicting modern society nowadays. In other words, ecology-themed tafsir is a framework of thinking in Tafsir Qur'an where the object of study is related verses from ecological themes and mufassir alignments on ecological problems that are very prominent.

Islamic people seem to be lagging in realizing environmental problems and coping solutions. In the West, ecology developed rapidly after the 1900s as a systematic and structured science then more rapidly in the last two decades. ${ }^{7}$ Based on the research done by J.J.G Jansen, as practical Tafsir is Tafsir emerged in the contemporary modern era, it can be concluded that ecological interpretations is emerged in the contemporary modern era. ${ }^{8}$

As it is popular that habl min Allab (establishing good relationship with Allah) and habl min al-nas (establishing good communication with humans), it is the proper time to pronounce habl ma'a al-bi'ab (establishing good communication with environment). The trilogy relationship among God as creator, humans as khalifah and the earth as living place needs to be maintained harmoniously in order to minimize inequalities occurred causing disaster. $^{9}$

\section{Akhlak (Morals)}

Etymologically, the word akblak is the plural form of kbuluq which means character, temperament, behavior, or character. ${ }^{10}$ It is rooted from the word khalaqa which means to create. It is also related to Khaliq (Creator), makhluq (creature) dan khalq (creation). ${ }^{11}$ Based on the similarities above, it implies that in akblak includes the understanding of integration between the will of Khaliq (God) and the behavior of beings (humans). With a semantic approach, that is more understandable, the statement above means that the behavior of a person towards another person and his new environment contains essential moral values when the action or behavior is based on the will of Khaliq (God). Morals are equated with decency, courtesy. Khuluq is an illustration of the inner nature of human outward forms, such as facial expressions, movements of limbs and the whole body. ${ }^{12}$ In Greek, the definition of khuluq is synonymous with the word ethico or ethos which means that there is a habit, an inner feeling, a tendency of the heart to do an action. Then, etbicos turn into ethics. $^{13}$

\footnotetext{
${ }^{7}$ Ahmad Suhendra, Menelisik Ekologis dalam al-Qur'an, Jurnal Esensia, Vol XIV No. 1 April 2013.

8 Abdul Mustaqim, Pergeseran Epistemologi Tafsir, (Yogyakarta: Pustaka Pelajar, 2008), p. 34-58.

${ }^{9}$ Ahmad Saddad, Paradigma Tafsir Ekologi, Jurnal Kontemplasi, Volume 05 Nomor 01, Agustus 2017.

10 A. Mustofa, Akblak Tasawuf, (Bandung: Pustaka Setia), 1997, p. 11.

${ }^{11}$ Yunahar Ilyas, Kuliah Akblaq, (Yogyakarta: Lembaga Pengkajian dan Pengamalan Islam LPPI,

${ }^{12}$ M. Yatimin Abdullah, Studi Akblak dalam Perspektif Alquran, (Jakarta: Amzah , 2007), p. 3.

13 Sahilun A. Nasir, Tinjanan Akblak, (Surabaya: Al-Ikhlas), 1991, p. 14.
} 2005), p. 1. 
Akblak, interpreted as the science of manners, ${ }^{14}$ is science that seeks to recognize human behavior and gives value to good or bad deeds according to norms and moral conduct. Terminologically, although some experts have different idea, they still have the same core. Abdul Hamid says that morality is the knowledge of virtue that must be done for filling the soul with goodness and avoiding evil, therefore, his soul is empty of all forms of evil. ${ }^{15}$

Imam al-Ghazali said that akblak is a character embedded in the soul which creates various kinds of actions easily without any thought or consideration. ${ }^{16}$ In essence, khuluq (character) or akblak is a condition or trait that has permeated the soul and become a personality. Furthermore, various kinds of act arise spontaneously without being made up and without the need for thought. Another term that is closely related to akblak is moral. Moral comes from English language (moral), Latin (mores), and Dutch language (moural) which means character, morality and customs. According to The Advenced Learners Dictionary of Current English, moral is related to the principles of right and wrong, good and bad, the ability to know the difference between right and wrong, and the teaching or description of good human behavior. ${ }^{17}$

Among akblak, ethic, moral, and morality have a difference nuance and a close relationship at once. All of them have diverse sources and focus, namely, revelation, reason and customs. Akblak and ethics, for example, cannot be equated as on the one hand, ethics is confused with courtesy between fellow humans and only related to physical deeds. Akblak, on the other hand, is broader in meaning and scope which is not only in terms of external character, but also including things inward and in nature. The source of akblak is Qur'an and hadith. Akblak include various aspects, including akblak to God and akblak to their fellow beings, both animate and inanimate.

\section{Natural Disaster}

Law Number 24 Year 2007 concerning Disaster Management states the definition of disaster as an event or series of events that threatens and disrupts the lives and livelihoods of people caused by natural factors and / or non-natural factors and human factors, resulting in human casualties, environmental damage loss of property and psychological impact. $^{18}$

As stated above, disasters are caused by natural, non-natural, and human factors. Therefore, Law Number 24 Year 2007 also defines natural disasters, non-natural disasters, and social disasters. Natural disasters are disasters caused by events or a series of events caused by nature such as earthquakes, tsunamis, volcanic eruptions, floods, droughts,

\footnotetext{
${ }^{14}$ Husin Al-Habsy, Kamus Al-Kautsar, (Surabaya: Assegaf, tt.), p. 87.

15 Abdul Hamid Yunus, Da’irab al-Ma'arif, Asy-Sya’ib, (Kairo, tt.), p. 936.

${ }^{16}$ Imam al-Ghazali, Ibya al-'Ulum al-Din, al-Masyhad al-Husain, (Kairo, tt.), p. 56.

${ }^{17}$ J.B. Dykes, (ed.), The Concise Oxford Dictionary of Current English, (London: Oxford University Press, 1976), p. 708

18 Anonim, Definisi dan Jenis Bencana, taken from Badan Pusat Penanggulangan Bencana (BNPB) website, accessed on 21 Maret 2018 dari https://www.bnpb.go.id/home/definisi
} 
hurricanes, and landslides. Non-natural disasters are disasters caused by events or series of non-natural events which include technological failures, failure of modernization, epidemics, and epidemics. Social disasters are disasters caused by events or a series of events that are caused by humans which include social conflicts between groups or between community communities, and terror. ${ }^{19}$

According to al-Qur'an, every disaster (corruption throughout the land and the sea) has appeared by reason of what the hands of people have earned (ar-Ruum [30]: 41). In a number of verses, Allah forbids all forms of environmental damage and excessive exploitation of nature such as not committing abuse on the earth, spreading corruption (Hud [11]: 85), paying attention to the consequences received by the previous people who committed destruction on earth (al-A'ràf [7]: 86), and avoiding factors that cause damage (al-Baqarah [2]: 11-12). Alhough nature is created for humans to be used for their survival; humans are required to be wise in managing nature.

In ar-Ruum [30]: 41, term fasad means something out of balance. This concerns the soul / spirit, body / physical, and anything that deviates from the balance / the right thing. In al-Qur'an, if fasad forms mashdar and stands alone, then it shows physical / physical damage, such as flooding, air pollution, etc .; and if it is in the form of a verb (fi'it) or mashdar form but previously there is a ficil sentence, the most is showing the meaning of damage that is non-physical / ma'nawi, such as kafir, syirik, hypocrites, and etc.. ${ }^{20}$ Mufassir explains the forms of damage on land and sea, with different tafsir, including; big flood, bad season, lack of water, ${ }^{21}$ vain death, fire, injustice, heretical behavior, ${ }^{22}$ crop failure and economic crisis. $^{23}$

\section{Natural Disasters Caused in the Former Tribes}

First, The Deluge inflicted Noah tribe ${ }^{24}$ is mentioned in almost all cultures, not just the Qur'an. Noah was sent to remind his people who had left the verses of Allah as well as committed heresy, invite them to worship Allah and stop their heresy. Even though Noah had advised his followers many times to obey the commands and reminded of the wrath of Allah, they still refused and continued to commit heresy. For this reason, Allah told Noah that those who rejected the truth and made mistakes would be punished by drowning, and those who believe will be saved. Therefore, when the punishment came, a very heavy flow of water appeared and gushed from the ground, accompanied by very heavy rain causing severe flooding. All humans on the land sank except those who took board the ship of

\footnotetext{
19 Ibid.

${ }^{20}$ Reflita, Eksploitasi Alam Dan Perusakan Lingkungan : Istinbath Hukum Atas Ayat-Ayat Lingkungan, Jurnal Substantia, Volume 17 Nomor 2, Oktober 2015.

${ }^{21}$ Ar-Ràziy, Mafàtih al-Gaib, volume XII, p. 245.

${ }^{22} \mathrm{Ibnu}$ 'Àsyùr, , at-Tahrì wa at-Tanwìr, volume IV, p. 486.

${ }^{23}$ Az-Zamakhsyariy, Tafsir al -Kasysyäf' 'an Haqà'iqut-Tanzill wa 'Uyun al-Aqàwil, Juz 3, (Beirut: DārulKutub, t.tp.), p. 259.

${ }^{24}$ Further story of Noahh can be found on al-Qur'an Surat Al Mu'minuun [23]: 23-27; Al A'raaf [7]: 59; Asy Syu'araa' [26]: 107-115, 119; Nuh [71]: 1; Huud [11]: 26, 39, 40-44; Qamar [54]: 9; Haaqqah [69]: 1112; Ash Shaaffaat [37]: 79-81, Al Qamar [54]: 11-13; Al Ankabuut [29]: 15;
} 
Noah. Archaeological, geological and historical studies show that the event took place as told by the Qur'an. ${ }^{25}$

Earthquakes and volcanic eruptions of Lut is the second. Lut was sent as a prophet to a people who practiced deviant behavior that the world had not known at that time named sodomy. When Lut called on them to stop the deviation conveying Allah's warning, his people ignored it, denied his prophethood and continued their deviation. In the end they were destroyed by a terrible disaster. When the people of Lut were destroyed, only Lut and his followers were no more than "a family", who was saved. This is also written in asySyu'araa' verse 173, "And We rained upon them a rain [of stones], and evil was the rain of those who were warned...", and Huud verses 82, "So when Our command came, We made the highest part lof the city] its lowest and rained upon them stones of layered hard clay, [which were]". Lut tribe was estimated to live in an area that is now the Dead Sea. The findings of archaeologists confirm that the Dead Sea is located at the peak of an area as active as the earthquake (We made). The earthquake then caused a volcanic eruption (rained upon them stones of layered hard clay). ${ }^{26}$

Third is Sandstorm of Ad' Tribe. The 'Ad, based on the Qur'an, is people who build buildings in every high place and beautiful buildings wishing they will live there (forever). Hud was sent to the 'Ad people conveying Allah command to believe Him and not committing heresy. Therefore, as they responded with hostility, they were carried out with a terrible sandstorm as if they had never existed. In the early 1990s, it was estimated the city of 'Ad was found following by the findings of the relics of many works of art from advanced civilizations as mentioned in the Qur'an. ${ }^{27}$

There are still some tribes who were annihilated by Allah in the Qur'an such as the Saba 'and the Thamud, but presumably the three tribe stories described above are enough as representation. In conclusion, the people who were annihilated by God were those people who behave badly both in habluminallah and habluminannas. Because of that, a natural disaster (with the permission of Allah) came upon them.

\section{Pompeii and Legetang}

The story of destroyed people are not only be found in the Qur'an. One of UNESCO's world heritage attractions, the world's most valuable archaeological site nowadays, the ancient city buried in Italy, Pompeii, was predicted to be a city destroyed by God because of its bad deeds. On August 24, 79 AD, Mount Vesuvius erupted violently. It spewed 100 feet of ash into the air for 18 hours, which fell into the city, strangling residents and covering the building. The deadly disaster occurred the next day, when the cone of the volcano's cone collapsed, causing a mud slide to flood Pompeii ${ }^{28}$

\footnotetext{
${ }^{25}$ Harun Yahya, Pustaka Sains Populer Islami: Jejak Bangsa-Bangsa Terdahulu, (Bandung: Dzikra, 2004), p. 5-6.

26 Ibid., p. 35-40.

${ }^{27}$ Ibid., p. 54-58.

${ }^{28}$ Victoria Woollaston, Revealed - what's inside the Pompeii mummies: Incredible CT scans show bodies in unprecedented detail laying bare their bones, delicate facial features and even perfect teeth, 29 September 2015, accessed on
} 
Pompeii was a home for around 13,000 people when it was buried under ash, hot gravel and dust due to volcanic eruptions with the strength of 40 atomic bombs. Two thirds of the total city area totaling 66 hectares was found. This site attracts more than two million tourists every year and makes it one of the most popular attractions in Italy. ${ }^{29}$

The city was discovered around the end of the 16th century, but it was only truly explored in the 18th century by Italian archaeologist Guiseppe Fiorelli. This is because excavators are shocked by frescoes describing sexual things explicitly. For the sensitivity / awareness of the medieval inhabitants of Rome reason, they covered it again. ${ }^{30}$ When the excavation was carried out again two centuries later, archaeologists found that almost the entire city was still intact including pieces of bread still in the oven, male bodies, women, children and pets found petrified in their last position expressing of fear still on their faces. Archaeologists identify many brothels throughout Pompeii - estimated to be around 35 with erotic paintings and graffiti adorning many rooms with stone mattresses. Archaeologists must be careful to determine the prostitution location with ordinary buildings. The testicles (phallus) were a common decoration for lucky charms in Pompeii and were painted in homes, on the streets, and in shops. ${ }^{31}$

A similar story was from Legetang, in Dieng area. Legetang, which is only 3 kilometers from Kawah Sileri, was buried by the landslides of Mount Pengamun-amun in 1955. The destruction of the Legetang was recorded by the USGS on June 9, 1971 in a report entitled Dieng Geothermal Area Evaluation of Initial Investigation, Central Java. 332 residents and 19 residents of the neighboring village were killed ${ }^{32}$

In 1955, as all equipment was limited, it was very difficult to evacuate buried residents. The local government at that time let the village buried. To date, the markers of the disaster were only inscriptions. After the landslide incident of Mount Pengamun-amun which removed Legetang, the government built a monument which was also installed inscriptions made of iron. The inscription is then affixed to a concrete wall bearing capital letters with the old spelling "TUGU PERINGATAN ATAS TEWASNJA 332 ORANG PENDUDUK DUKUH LEGETANG SERTA 19 ORANG TAMU DARI LAIN-LAIN DESA SEBAGAI AKIBAT LONGSORNJA GUNUNG PENGAMUN-AMUN PADA TG. 16/17-4-1955."

21 Maret 2018 from http://www.dailymail.co.uk/sciencetech/article-3253660/Peering-inside-Pompeii-stragic-victims-Incredible-CT-scans-reveal-bodies-unprecedented-laying-bare-bones-delicate-facial-featuresdental-cavities.html

${ }^{29}$ Elin Yunita Kristanti, Kota Kuno Pompeii Kembali Dibayangi Kehancuran, 3 Maret 2014, accessed on 21 Maret 2018 from http://global.liputan6.com/read/2017534/kota-kuno-pompeii-kembali-dibayangikehancuran

${ }^{30}$ Anonim, The Houses of Pleasure in Ancient Pompeii, 1 Agustus 2014, accessed on 21 Maret 2018 from http://www.ancient-origins.net/ancient-places-europe/houses-pleasure-ancient-pompeii-001925

${ }^{31}$ Teddy Tri Setio Berty, Ini 3 Kota Maksiat yang Binasa Akibat Kutukan Alam, 10 Januari 2018, accessed on 21 Maret 2018 from http://global.liputan6.com/read/3221990/ini-3-kota-maksiat-yang-binasaakibat-kutukan-alam

${ }^{32}$ Arie Mega Prastiwi, Fakta Vs Kisah Mistis Dusun di Diengyang Lenyap dalam Semalam, 3 Juli 2017, accessed on 21 Maret 2018 from http://global.liputan6.com/read/3009902/fakta-vs-kisah-mistis-dusun-didieng-yang-lenyap-dalam-semalam 
As Pompeii, the rumors spread that disaster happened because of people actions, as well as Legetang. Many local residents stated that Legetang was buried because of his ignorant people. Given the fertil land, they denied the favor by not living a religious life properly. ${ }^{33}$

A scientific explanation illustrates that Dieng has steep contours which is flanked by steep two mountain cliffs. The Dieng area, which is prone to disasters, Dieng people have exacerbated the potential for landslides by utilizing steep slopes for agriculture. In terms of science, it is natural that a village like Legetang is buried. ${ }^{34}$

\section{Unseen Side of the Universe}

As we know, the universe s everything that is in the sky and on earth. As Muslims, we believe that the universe is a creation of Allah. In Qur'an, Allah confirms that his universe is always submissive, prostrate and glorifies Him. Here are some verses that explain it.

\begin{tabular}{|c|c|c|}
\hline No & Surah [Verse] & Explanation \\
\hline 1 & Ali Imran [3]: 83 & $\begin{array}{l}\text { "So is it other than the religion of Allah they desire, while to Him have } \\
\text { submitted [all] those within the heavens and earth, willingly or by } \\
\text { compulsion, and to Him they will be returned?." }\end{array}$ \\
\hline 2 & $\begin{array}{l}\text { Al Baqarah [2]: } \\
116\end{array}$ & $\begin{array}{l}\text { "They say, " Allah has taken a son." Exalted is He! Rather, to Him } \\
\text { belongs whatever is in the heavens and the earth. All are devoutly obedient } \\
\text { to Him." }\end{array}$ \\
\hline 3 & An-Nahl [16]: 49 & $\begin{array}{l}\text { "And to Allah prostrates whatever is in the heavens and whatever is on } \\
\text { the earth of creatures, and the angels [as well], and they are not } \\
\text { arrogant.." }\end{array}$ \\
\hline 4 & Al-Haji [22]: 18 & $\begin{array}{l}\text { "Do you not see that to Allah prostrates whoever is in the heavens and } \\
\text { whoever is on the earth and the sun, the moon, the stars, the mountains, } \\
\text { the trees, the moving creatures and many of the people? But upon many } \\
\text { the punishment has been justified. And he whom Allah humiliates - for } \\
\text { bim there is no bestower of honor. Indeed, Allah does what He wills." }\end{array}$ \\
\hline 5 & Ar-Ra'd [13]: 15 & $\begin{array}{l}\text { "And to Allah prostrates whoever is within the heavens and the earth, } \\
\text { willingly or by compulsion, and their shadows [as well] in the mornings } \\
\text { and the afternoons." }\end{array}$ \\
\hline
\end{tabular}

33 Arie Mega Prastiwi, 2 Kisah 'Horor' di Dieng: Tragedi Sinila dan Raibnya Legetang, 3 Juli 2017, accessed on 21 Maret 2018 from http://global.liputan6.com/read/3009275/2-kisah-horor-di-dieng-tragedi-sinila-danraibnya-legetang

34 Arie Mega Prastiwi, Fakta Vs Kisah Mistis Dusun di Dieng yang Lenyap dalam Semalam, 3 Juli 2017, accessed on 21 Maret 2018 from http://global.liputan6.com/read/3009902/fakta-vs-kisah-mistis-dusun-didieng-yang-lenyap-dalam-semalam 
6 Al-Isra" [17]: $44 \quad$ "The seven heavens and the earth and whatever is in them exalt Him. And there is not a thing except that it exalts [Allah] by His praise, but you do not understand their [way of] exalting. Indeed, He is ever Forbearing and Forgiving."

There are two opinions of Ulama related to submission, prostration and tasbih of the universe towards Allah. Some Ulama interpret it in the sense of majazi and some others in an intrinsic sense. In the majazi sense, submission, prostration and tasbih of the universe is in the sense of obedience to Allah command that apply to them. The universe is always obedient to Allah command determined in the system. ${ }^{35}$

From the opposite side, al Biqa'i tries to understand it in the suprarational essential meaning. Al-Biqa'i refers to Bukhari's hadith about the tasbih of food when it is eaten and the tasbih of stones. He states that some people can understand the tasbih of all things, but it is not applied to most people. Al Biqa'i knows inability to comprehend the tasbih happened at most people, but for those who are obedient and steadfast can understand it. ${ }^{36}$

Ulama who are in the same boat are Thabathaba'i, a Shia scholars and philosophers. He tends to intrinsic meaning. He raises a rebuttal if tasbih is the obedience of all things to the system established by Allah, which is also understood by humans - even for the present - as the heretic may have a better understanding than Muslims - while the verse above expressly states that you, $\mathrm{O}$ whole man - or you $\mathrm{O}$ heretical people do not understand their prayer beads.

Thabathaba'i describes further, tasbih is not merely revealing about the sanctity of Allah from all shortcomings. It is called as tasbih when it is accompanied by the intention of the person concerned, while the existence of conditional intentions with life, even though most of those who live on earth and heaven and inanimate objects do not have life. ${ }^{37}$

It is repeatedly found Allah word about Tasbih for heaven and the earth and what is contained in them. Some of them cannot be understood except in the essential sense, like His words:

\begin{tabular}{lcc}
\hline No & Surah [Verse] & Explanation \\
\hline $\mathbf{1}$ & Al Anbiya [21]: 79 & "And We gave understanding of the case to Solomon, and to each [of \\
& & them] We gave judgement and knowledge. And We subjected the \\
& & mountains to exalt $[\mathrm{Us}]$, along with David and [also] the birds. And \\
\hline
\end{tabular}

${ }^{35}$ Quraish Shihab, Tafsir al-Mishbah, Pesan, Kesan, dan Keserasian al-Qur'an, Jakarta: Lentera Hati, 2012, volume 7, p. 102.

${ }^{36}$ Ibid., p. 103.

${ }^{37} \mathrm{Ibid}$, p. 106. 
Millatī, Journal of Islamic Studies and Humanities, Vol. 4, No. 1, Juni 2019: 53-68

\begin{tabular}{ll}
\hline We were doing [that]." \\
\hline "Indeed, We subjected the mountains [to praise] with bim, exalting [ \\
Allah] in the [late] afternoon and [after] sunrise."
\end{tabular}

This means that what is done by mountains and birds is a privilege of David, while if what is meant by repeating their tasbih is their harmony and obedience to the natural laws created by Allah which can be understood by many people as this is no longer a privilege for David.

Therefore, Quraish Shihab also tends to state that creatures are glorified and we do not need to discuss how to worship after Allah affirms that you (O people) do not understand their prayer beads because their prayer beads are not using language and the way you worship and are also beyond your reasoning ability you reach it. ${ }^{38}$

Here, the writer concludes that the universe has an unseen side (if not spirit, because spirit is associated with life, and can be misunderstood as animism and dynamism), a side that humans do not understand because they cannot be detected by the senses. Furthermore, the unseen side of the universe has a power relationship with the unseen side (soul) of humans.

\section{The Correlation of Natural Disasters with Human Akhlak}

Ecological-themed Tafsir as part of a scientific interpretation is still much debated. Sciencethemed Tafsir existed all this time are struggling in matching scientific findings with the verses of the scriptures. According to some people, Science-themed Tafsir has a pseudoscience image or a Bucaillian justification model. Though pseudoscience is a claim, belief, or practice presented as scientific, it does not follow a valid scientific methodology. As it cannot be reliably tested, it does not have supporting or reasonable evidence and scientific status. Pseudoscience is often characterized by using vague, exaggerated or unproven claims, highly dependent on confirmation rather than strict denial efforts, lacking openness for evaluation by other experts, and having no systematic process for developing rational theories. Meanwhile, the Bucaillian justification model was taken from the name Maurice Bucaille, a French medical expert, who had stirred the Islamic world when writing a book entitled "La Bible, le Coran et la Science" (Bibel, Qur'an and Science). ${ }^{39}$

\footnotetext{
38 Ibid., p. 109-110.

${ }^{39}$ Mohamad Muslih, Sains Islam Dalam Diskursus Filsafat Ilmu, Kalam: Jurnal Studi Agama dan Pemikiran Islam, Volume 8, Nomor 1, Juni 2014, p. 2.
} 
The question is "Is this scientific interpretation really unscientific and rational?" This problem leads to the division of knowledge into a science of religion known as suprarational (or irrational) and general science which is rational. In Qur'an, there is no difference in knowledge. Distinguishing science is not known at the time of the decline of the Qur'an and even not introduced by Allah. He does not know the terms of religion and general science as all knowledge comes from Him. What He introduced was the knowledge acquired by human effort Kasby (acquired knowledge) and knowledge which was the gift of Allah without effort. ${ }^{40}$

From the medical field, for example, at first the doctors did not see a connection between the physical illness that a person suffered from his condition and his condition. In contrast, since the beginning of the nineteenth century, medical experts have begun to realize that there is a connection between disease and human psychological conditions. This reciprocal relationship can cause humans to suffer physical disorders caused by mental disorders (somapsikotis) and mental disorders can cause physical illness (psikosomatik). ${ }^{41}$ Some findings in the medical field were found in a number of cases which proved the existence of a soul (psyche) and body relationship (soma). People who feel scared, immediately lose appetite, or diarrhea. Moreover, in a state of irritation, a person's stomach feels bloated etc. ${ }^{42}$ Mental health cannot be separated from religious participation in which how beliefs and practices of practicing religion ffect their mental health. ${ }^{43}$

Islam emphasizes the need for a balance between physical and spiritual health. Humans are said balance if they are healthy in both of them. If the balance is disrupted, it causes problem. Therefore, it does not deviate if we also apply it to the universe / environment we live. We do not only conserve the physical but also the supernatural by maintaining our akblak. The detailed explanation is explained as follows.

As stated earlier, the occurrence of natural damage and natural deviations induce disasters are caused by human actions. Even so, some mufassir define the sentence above not only to show human behavior directly in the context of natural damage, such as illegal logging, carelessly dispose of garbage, dispose of industrial waste without regard to ecosystems, etc., but also refers to non-physical behavior, such as polytheism, hypocrisy and all forms of immorality. It means the deviation of faith and immoral behavior cause environmental damage. However, ar-Raziy gives an affirmation that polytheism and kufr are not only in the level of aqidah but also in behavior in which fasiq is considered as syirik in the context of deeds not beliefs ${ }^{44}$

${ }^{40}$ Quraish Shihab, Tafsir al-Mishbah, Pesan, Kesan, dan Keserasian al-Qur'an, Jakarta: Lentera Hati, 2012, volume 5, p. 289.

41 Abdul Hamid, Agama dan Kesehatan Mental Dalam Perspektif Psikologi Agama, Jurnal Kesehatan Tadulako, Vol. 3 No. 1, Januari 2017 : 1-84, p. 3.

42 Ibid., p. 6-7.

43 Ibid., p. 13.

44 Ar-Raziy, Mafàtih al-Gaib, volume XII, p. 245. 
From the explanation above, it is known that disasters and environmental damage are due to the destruction of human mentality or morality. This mental damage encourages people to carry out destructive behaviors, both directly related to the destruction of nature, such as illegal logging, building buildings in places where water is absorbed, damming river channels so that they are narrowed and so on or indirectly related, such as corruption, bribery, abuse of office, economic crime, and others.

Physical damage is also a result of non-physical or mental damage. If this deviant behavior continues massively and entrenched, it will impact on acts of environmental destruction which ultimately lead to disasters. Allah gives disaster to humans, for they can feel the consequences of their actions and return to obey Him. Damaging the environment is characterized by God, as a hypocritical character. They claim to be people who do good. In fact, if they walk on the earth, they deliberately do damage and destroy plants and livestock. In another verse, environmental destroyers are labeled as ecological infidels (kufr al-bi'ab).

Among the signs of the greatness of God is the existence of this universe. For this reason, damaging the environment is the same as that of the Gentiles (Shàd [38]: 27). Understanding Nature in vain is the view of unbelievers. Moreover, he got to do destruction of nature. The word pagan in the Qur'an is not only always related to the creed, but also related to the Mu'amalah. In Surah Al-Baqarah [2]: 26-27, categorized infidels, people who violate the Covenant of God (Kufur Creed), decide what God commanded to be connected (Kufur Insaniyyah or Ijtima'iyyah) and do damage to the Earth (Kufur Kauniah / ecology).

If we pay close attention, the disasters that these people receive are not disasters that have a direct causal relationship with human actions on the environment, such as trash dumping resulting flood, illegal logging causing landslides. It is categorized in natural factors disaster science humans do not contribute to such as earthquakes and volcanoes. Furthermore, the flood inflicted on Noah tribe was also not a flood of direct action from humans, such as building narrow houses on the river and so on, but it was categorized in natural factor disasters without human contributions. Therefore, from all the above explanations, the authors conclude that besides there is a direct causal relationship between the universe or the environment with humans, there is also an indirect causality between the unseen side of the universe (which is submissive, prostrate, and prayer beads to) with the spiritual side of human. If the human spirit is good, the supernatural side will also be good for humans, on the contrary, if the human spirit is bad, the supernatural side will not like and with the permission of Allah, it will bring disaster / destruction to humans. Therefore, in order to maintain nature, it is not only effort in direct causality that we must do, but it is supplemented by efforts in indirect causality. 


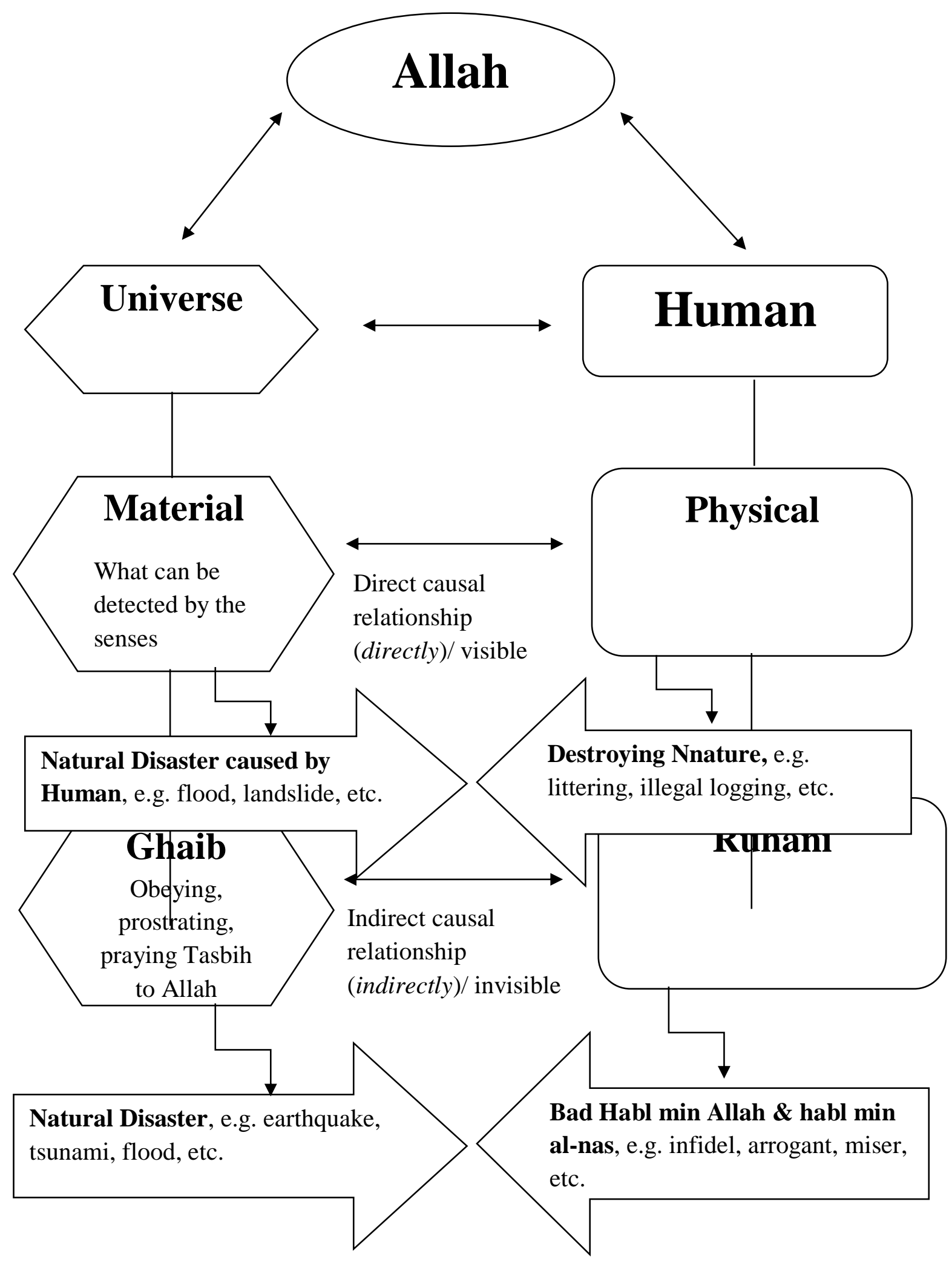

\section{CONCLUSION}

A quality environment has a concept that is closely related to the concept of quality of life. An environment that can support a good quality of life means having a good quality in its 
environment. The concept of quality of life is the degree of fulfillment of basic human needs. The better the basic needs can be met by the environment, the higher the quality of the environment. As environmental problems increase along with changing societies, approach to maintain the universe needs to be developed for a better result.

The writer seeks to offer a solution to safeguard our natural environment from the material side and the occult side. The material side is with our outer efforts such as in science which has been widely studied in which human exploit nature normally. The supernatural side that is often forgotten and which is widely considered mystical and unreasonable is actually agreed by Qur'an. This side is closely related to our efforts to maintain akblak in relation to Allah and other humans. With a balanced effort between the two sides, it is expected that this nature will be better. In a nutshell, this is all for the good of us (humans) themselves.

\section{REFERENCES}

Abdullah, M. Yatimin, Studi Akblak dalam Perspektif Alquran, Jakarta: Amzah, 2007.

Al-Ghazali, Imam, Ibya al-Ulum al-Din, Kairo: al-Masyhad al-Husain, tt.

Al-Habsy, Husin, Kamus Al-Kautsar, Surabaya: Assegaf, tt.

Al-Sabuni, Muhammad Ali, Al-Tibyan Fi 'Ulum Al-Qur'an, Jakarta: Dar AlIslamiyah, 2003.

Anonim, Definisi dan Jenis Bencana, diambil dari laman Badan Pusat Penanggulangan Bencana (BNPB), 21 Maret 2018. https://www.bnpb.go.id/home/definisi

Anonim, The Houses of Pleasure in Ancient Pompeii, 1 Agustus 2014, diakses 21 Maret 2018 dari http://www.ancient-origins.net/ancient-places-europe/houses-pleasure-ancientpompeii-001925

Az-Zamakhsyariy, Tafsir al-Kasysyaf 'an Haqa'iqut-Tanzil wa 'Uyun al-Aqawil, Juz 3, Beirut: Dārul-Kutub, tt.

Berty, Teddy Tri Setio, Ini 3 Kota Maksiatyang Binasa Akibat Kutukan Alam, 10 Januari 2018, diakses 21Maret 2018 dari http://global.liputan6.com/read/3221990/ini-3-kotamaksiat-yang-binasa-akibat-kutukan-alam

Hamid, Abdul, Agama dan Kesehatan Mental Dalam Perspektif Psikologi Agama, Jurnal Kesehatan Tadulako Vol. 3 No. 1, Januari 2017 : 1-84.

Ilyas, Yunahar, Kuliah Akhlaq, Yogyakarta: Lembaga Pengkajian dan Pengamalan Islam (LPPI), , Cet. VII, 2005.

JB. Dykes (ed.), The Concise Oxford Dictionary of Current English, London: Oxford University Press, 1976. 
Kristanti, Elin Yunita, Kota Kuno Pompeii Kembali Dibayangi Kehancuran, 3 Maret 2014, diakses 21 Maret 2018 dari http://global.liputan6.com/read/2017534/kota-kuno-pompeiikembali-dibayangi-kehancuran

Mangunjaya, Fachruddin M., Konservasi Alam dalam Islam, Jakarta: Yayasan Obor Indonesia, 2005.

Muslih, Mohamad, Sains Islam Dalam Diskursus Filsafat Ilmu, Kalam: Jurnal Studi Agama dan Pemikiran Islam Volume 8, Nomor 1, Juni 2014.

Mustaqim, Abdul, Dinamika Sejarah Tafsir al-Qur'an, Yogyakarta: Adab Press, 2014.

Mustaqim, Abdul, Pergeseran Epistemologi Tafsir, Yogyakarta: Pustaka Pelajar, 2008.

Mustofa, A., Akblak Tasawnf, Bandung: Pustaka Setia, 1997.

Nasir, Sahilun A., Tinjauan Akblak, Surabaya: Al-Ikhlas, 1991.

Prastiwi, Arie Mega, 2 Kisah 'Horor' di Dieng: Tragedi Sinila dan Raibnya Legetang, 3 Juli 2017, diakses 21 Maret 2018 dari http://global.liputan6.com/read/3009275/2-kisahhoror-di-dieng-tragedi-sinila-dan-raibnya-legetang

Prastiwi, Arie Mega, Fakta Vs Kisah Mistis Dusun di Diengyang Lenyap dalam Semalam, 3 Juli 2017, diakses pada 21 Maret 2018 dari http://global.liputan6.com/read/3009902/fakta-vs-kisah-mistis-dusun-di-diengyang-lenyap-dalam-semalam

Reflita, Eksploitasi Alam dan Perusakan Lingkungan (Istinbath Hukum Atas Ayat-Ayat Lingkungan), Jurnal Substantia, Volume 17 Nomor 2, Oktober 2015.

Resosoedarmo, Soedjiran, dkk, Pengantar Ekologi, Bandung: Remadja Karya Cv, 1984.

Saddad, Ahmad, Paradigma Tafsir Ekologi, Jurnal Kontemplasi, Volume 05 Nomor 01, Agustus 2017.

Sastrawijaya, Tresna, Pencemaran Lingkungan, Jakarta: Rineka Cipta 2000.

Shihab, Quraish, Tafsir al-Mishbah, Pesan, Kesan, dan Keserasian al-Qur'an, Jakarta: Lentera Hati, 2012.

Suhendra, Ahmad, Menelisik Ekologis dalam al-Qur'an, Jurnal Esensia vol XIV No. 1 April 2013.

Woollaston, Victoria, Revealed - what's inside the Pompeii mummies: Incredible CT scans show bodies in unprecedented detail laying bare their bones, delicate facial features and even perfect teeth, 29 September 2015, diakses 21 Maret 2018 dari http://www.dailymail.co.uk/sciencetech/article-3253660/Peering-inside-Pompeii- 
Millatī, Journal of Islamic Studies and Humanities, Vol. 4, No. 1, Juni 2019: 53-68

s-tragic-victims-Incredible-CT-scans-reveal-bodies-unprecedented-laying-barebones-delicate-facial-features-dental-cavities.html

Yahya, Harun, Pustaka Sains Populer Islami: Jejak Bangsa-Bangsa Terdabulu, Bandung: Dzikra, 2004.

Yunus, Abdul Hamid, Da'irab al-Ma'arif, Kairo: Asy-Sya'ib, tt. 